\author{
MAREK HENDEL \\ Uniwersytet Ekonomiczny w Katowicach, Polska \\ University of Economics in Katowice, Poland
}

\title{
Produkt obszaru recepcii turystycznej w odniesieniu do konsumpcii zrównoważonej w turystyce. Wstęp do dyskusji
}

\section{Tourism Destination Product in Reference to Sustainable Consumption in Tourism. Introduction to a Discussion}

\begin{abstract}
Streszczenie: Artykuł ma na celu odniesienie produktu obszaru recepcji turystycznej do konsumpcji zrównoważonej w turystyce poprzez bliższe przedstawienie obu pojęć oraz ich bezpośrednie zestawienie ze sobą na podstawie wyszczególnionych cech produktu obszaru recepcji turystycznej. Podejmując rozważania na gruncie konsumpcji zrównoważonej w turystyce, uwzględniając również wskazywaną konieczność badań nad zrównoważonym rozwojem w odniesieniu do przestrzeni, autor wybrał szczególny dla tej tematyki przedmiot badawczy, jakim jest produkt obszaru recepcji turystycznej. Zdaniem autora jest to zagadnienie wymagające szczególnego odniesienia do konsumpcji zrównoważonej w turystyce, ze względu na swą ogólną specyfikę, różnorodność potrzeb zgłaszanych przez turystów oraz zróżnicowany stopień zaangażowania w proces zaspokajania własnych potrzeb. Dyskusja nad ogólnymi pojęciami obszaru recepcji turystycznej i konsumpcji pokazała, że już na etapie dość ogólnych wniosków pojawiają się wątpliwości i niejednoznaczność. Próba odniesienia pojęcia produktu obszaru recepcji turystycznej do konsumpcji zrównoważonej w turystyce wydaje się więc wyzwaniem szczególnym, które zdaniem autora wymaga dalszych badań. Przedstawione w artykule rozważania mogą stać się przyczynkiem do dyskusji.
\end{abstract}

\begin{abstract}
The aim of this article is to refer tourism destination product to sustainable consumption in tourism. Realization of this aim was possible by theoretical presentation and directly compiling of both concepts. The starting point of them was a specification of the features of tourism destination product. Decision about choosing the issues was a result of literature review on sustainable development. The researchers highlight that further consideration will be concentrating on space (as one of areas of implementation of sustainable development) and sustainable consumption. In the author's opinion the issues presented should be particularly related to tourism sector. The basic reasons for this approach are: specifics of tourism destination product; differences in tourists' needs; varied degree of satisfying tourists needs. The general consideration of consumption and tourism destination showed that no clear conclusions can be drawn. In relation to the above, in the author's opinion the reference of tourism destination product to sustainable consumption in tourism seems like a challenge. The issues mentioned in the article can serve as a starting point of a discussion.
\end{abstract}

Słowa kluczowe: produkt obszaru recepcji turystycznej; rozwój turystyki; turystyka zrównoważona; zrównoważona konsumpcja; zrównoważona konsumpcja w turystyce; zrównoważony rozwój 
Keywords: sustainable consumption; sustainable consumption in tourism; sustainable development; sustainable tourism; tourism destination product; tourism development

Otrzymano: 9 października 2017

Received: 9 October 2017

Zaakceptowano: 14 maja 2018

Accepted: 14 May 2018

\section{Sugerowana cytacja / Suggested citation:}

Hendel, M. (2018). Produkt obszaru recepcji turystycznej w odniesieniu do konsumpcji zrównoważonej w turystyce. Wstęp do dyskusji. Prace Komisji Geografii Przemysłu Polskiego Towarzystwa Geograficznego, 32(2), 278-288. https://doi.org/10.24917/20801653.322.19

\section{WSTĘP}

Na początku lat siedemdziesiątych XX wieku uważano, że ruchliwość przestrzenna i turystyka zaczynają stawać się aspektami życia człowieka współczesnego (Przecławski, 1973). Założenie to w swej prostocie niesie za sobą kilka fundamentalnych kwestii, które nie tylko można, ale i powinno się odnieść do czasów obecnych. W pierwszej kolejności można śmiało zadeklarować, że grono sceptyków zastanawiających się nad ogólnym znaczeniem turystyki już dawno przekonały statystyki zawarte w raportach Światowej Organizacji Turystyki, m.in. powszechnie cytowany wskaźnik międzynarodowych podróży turystycznych, który w 2012 roku wskazał po raz pierwszy liczbę 1 mld (UNWTO, 2013). Kolejną kwestią jest, rzadko dziś stosowane, określenie ruchliwości przestrzennej. W zestawieniu z turystyką określenie to powoduje, że akcent rozważań nakierowany jest na przestrzeń, stanowiącą kluczowy element zjawiska turystyki. B. Meyer (2011) zwraca przy tym uwagę, że pomiędzy turystyką a przestrzenią nie występuje relacja jednostronna, lecz pewnego rodzaju interakcja zakładająca wzajemne oddziaływanie. W tym przypadku nie bez znaczenia jest charakter wspomnianego oddziaływania, który może być zarówno pozytywny, jak i negatywny.

Odwołanie do lat siedemdziesiątych XX wieku nie jest przypadkowe. Wspomniane lata to okres wzrostu zainteresowania skutkami działalności człowieka, głównie w obszarze jego wpływu na środowisko przyrodnicze. To wówczas pierwszy raz posłużono się koncepcją zrównoważonego rozwoju i zaprezentowano ją. Z czasem fundamentalnym znaczeniem dla jej konkretyzacji stało się pojęcie ładu, które w podstawowym ujęciu określane jest w obszarze społecznym, ekonomicznym i środowiskowym, natomiast w szerszym ujęciu uzupełniane jest o ład instytucjonalno-polityczny, a także przestrzenny (Borys, 2011). Przestrzeń w dyskusji nad zrównoważonym rozwojem coraz częściej zestawia się z koncepcjami wypracowanymi na gruncie nauk społecznych, w tym nauk ekonomicznych. Za przykład może posłużyć koncepcja konsumpcji zrównoważonej, uważana za jeden z najważniejszych elementów umożliwiających wdrożenie zrównoważonego rozwoju (Lorek, 2011). Badacze zagadnienia zalecają przy tym odniesienie do różnych sektorów gospodarczych w celu bliższego poznania i zidentyfikowania potencjalnych problemów, a przede wszystkim szybszej implementacji. Tymczasem badania w tym obszarze podejmowane są bardzo rzadko, czego przykładem jest sektor turystyki.

Podejmując rozważania na gruncie konsumpcji zrównoważonej w turystyce, uwzględniając również wskazywaną konieczność badań nad zrównoważonym rozwojem w odniesieniu do przestrzeni, autor wybrał szczególny dla tej tematyki przedmiot badawczy, jakim jest produkt obszaru recepcji turystycznej. Tym samym autor 
określił za cel główny artykułu odniesienie produktu obszaru recepcji turystycznej do konsumpcji zrównoważonej w turystyce. Realizację celu umożliwiło bliższe przedstawienie obu pojęć oraz ich bezpośrednie zestawienie ze sobą, na podstawie wyszczególnionych cech produktu obszaru recepcji turystycznej.

\section{KONSUMPCJA ZRÓWNOWAŻONA W TURYSTYCE}

Zmiana charakteru konsumpcji, wraz ze zmianą stylów życia i zaspokajania potrzeb, pojawia się wśród najważniejszych wyzwań realizacji zrównoważonego rozwoju (Kiełczewski, 2012). Odpowiedzią na tak postawione wyzwanie jest konsumpcja zrównoważona, uznawana za „....konsumpcję świadomą, opartą na odpowiedzialności i wysokiej świadomości własnych potrzeb, co sprowadza się do podejmowania świadomych i odpowiedzialnych decyzji przez konsumenta" (Jaros, 2016: 26). Z kolei D. Kiełczewski (2008) wyróżnia dwa podejścia w interpretacji konsumpcji zrównoważonej, które opierają się w obu przypadkach na racjonalności wyborów nabywczych. Oba przypadki różnią się odmiennym postrzeganiem przeszkód prowadzących do racjonalności. W obu przypadkach osiągnięcie zrównoważenia odbywa się poprzez wybory konsumenckie, które nie powinny przyczyniać się do pogorszenia sytuacji innych konsumentów oraz uniemożliwiać im zaspokojenia ich fundamentalnych żywotnych potrzeb. Ponadto podejście konsumenta nie powinno prowadzić do ograniczania możliwości dokonywania wyborów konsumenckich w przyszłości, jak również zaspokojenia potrzeb przez przyszłe pokolenia. Warto przy tym dodać, że oparcie konsumpcji zrównoważonej na atrybucie racjonalności może stanowić zbyt duże uproszczenie, istnieją bowiem zachowania nabywcze, które nigdy nie posiadały w sobie racjonalności, lub istniały zjawiska, które znacznie je ograniczały (Kiełczewski, 2004).

W podejmowanych próbach interpretacji konsumpcji zrównoważonej bardzo często dochodzi do zaakcentowania podmiotowości konsumpcji i odwołania się do świadomości czy racjonalności działań konsumenta. Zdaniem M.H. Huang i R.T. Rust (2011), budowanie świadomości wśród konsumentów jest drogą do zrównoważonej przyszłości. Podejście to można również odnieść do turystyki, co przedstawiają dwa ujęcia (Hendel, 2016): szerokie, w którym świadomość ta dotyczy wiedzy o negatywnych skutkach niekontrolowanego wzrostu ruchu turystycznego na świecie; wąskie, w którym świadomość ta dotyczy możliwości etycznych i odpowiedzialnych wyborów podejmowanych przez jednostkę, a więc własnego udziału w rozwoju zrównoważonym.

Kierując rozważania $\mathrm{w}$ stronę turystyki, konsumpcja zrównoważona w swym ogólnym zakresie obejmuje również ten sektor. Specyfika rynku turystycznego nakazuje jednak ścisłe odniesienia do konsumpcji zrównoważonej, co wydaje się szczególnie uzasadnione. Spośród wielu obszarów realizacji zrównoważonego rozwoju to właśnie konsumpcja w turystyce wymieniana jest jako dająca rezultaty wdrożenia (Sharpley, 2015). Ponadto występuje konieczność bezpośredniego odniesienia konsumpcji zrównoważonej do różnych sektorów gospodarczych, czego szczególnym zwolennikiem jest T. Borys (2016), zwracający uwagę na inspirującą rolę nowych paradygmatów konsumpcji i produkcji w sektorowych operacjonalizacjach koncepcji rozwoju, eksponujących cechę równoważenia (jednym z wyróżnionych sektorów przez badacza była turystyka zrównoważona). Podkreślenie turystyki zrównoważonej nie jest przypadkowe, większość badaczy uznaje ją bowiem za model idealny w ściśle zachowanych warunkach równowagi pomiędzy środowiskiem przyrodniczym, turystami, społecznością 
lokalną i usługodawcami turystycznymi (Durydiwka, Kowalczyk, Kulczyk, 2010). Jednocześnie turystyka zrównoważona odwołuje się do ciągłego wzrostu konsumpcji dóbr i usług turystycznych, dążąc do niezmiennego zachowania stanu wzrostu w formie jak najbardziej przyjaznej środowisku (Zaręba, 2010), uwzględniając przy tym warunki ekonomicznego i społecznego rozwoju (Niezgoda, 2006).

Przedstawiając bliżej pojęcie konsumpcji zrównoważonej w turystyce, można odwołać się do definicji zaproponowanej przez M. Hendla (2016: 16), który określa ją jako „...konsumpcję dóbr i usług, opartą na świadomym i odpowiedzialnym wyborze decydującym o realizacji potrzeb turystycznych w sposób zrównoważony, tj. w sposób pozwalający na zachowanie stanu harmonii pomiędzy zgłaszanymi potrzebami turystów a lokalną społecznością i środowiskiem naturalnym, umożliwiając przez to przyszłym turystom realizowanie potrzeb na równym poziomie". Badacz wyszczególnia przy tym kilka cech szczególnych pojęcia (Hendel, 2016): wielowymiarowość - odwołująca się do zachowania stanu harmonii pomiędzy wieloma aspektami równoważenia; samoograniczenie - konsumpcja oparta na świadomym i odpowiedzialnym dokonywaniu wyborów przez konsumentów poprzez własne ograniczenia; minimalizacja negatywnych skutków konsumpcji oraz dążenie do całkowitej ich eliminacji; holistyczny wymiar konsumpcja zrównoważona jako jeden z elementów realizacji zasad zrównoważonego rozwoju w turystyce. Ponadto M. Hendel (2016) odwołuje konsumpcję zrównoważoną w turystyce do ogólnych cech zrównoważonego rozwoju, a więc trwałości, samopodtrzymywania oraz równoważenia: cecha trwałości dotyczy stałego wzrostu konsumpcji wśród turystów, umożliwiając przyszłym turystom konsumpcję na równym poziomie; samopodtrzymywanie oznacza utrwalanie aktualnego stanu konsumpcji zrównoważonej, prowadząc do dalszego jej rozwoju; cecha równoważenia wymaga zachowania równowagi i harmonii w procesie konsumpcji, obejmując m.in. aspekty ekonomiczne, ekologiczne, społeczne. Dodać można, że cecha równoważenia będzie dotyczyła w tym przypadku również przestrzeni.

\section{PRODUKT OBSZARU RECEPCJI TURYSTYCZNEJ}

Jedną z podstawowych kategorii w analizie zjawiska turystyki jest obszar recepcji turystycznej, który najogólniej oznacza miejsce, do którego kieruje się ruch turystyczny, i w zależności od sytuacji może odnosić się do gminy, regionu lub kraju (Cieślikowski, Żemła, 2002). Pomimo powszechnie funkcjonującego pojęcia, nie wypracowano dotychczas jednej akceptowalnej definicji, która mogłaby całkowicie oddać złożoność obszaru recepcji turystycznej - analizy krytycznej pojęcia dokonał m.in. M. Żemła (2010), Ł. Nawrot i P. Zmyślony (2009) czy M. Smoleński (2012).

Za interpretację bliską ukazania całości pojęcia obszaru recepcji turystycznej, łączącą w sobie różne ujęcia problemu (m.in. cechy ujęcia popytowego i podażowego), można uznać definicję zaproponowana przez M. Żemłę (2010: 29), który obszar recepcji turystycznej określa jako „...dowolny obszar (miejscowość lub jej część, grupa miejscowości, region, państwo) będący miejscem koncentracji ruchu turystycznego i wywołanych przez niego skutków społeczno-ekonomicznych i przyrodniczych, posiadający takie walory i zagospodarowanie turystyczne, że postrzegany może być przez turystów jako odrębna i jednolita całość, i jest przez nich traktowany jako jedna z dostępnych alternatyw (marek) branych pod uwagę w procesie podejmowania decyzji o wyborze produktu turystycznego". Ponadto zdaniem M. Żemły (2010), w ramach obszaru recepcji 
turystycznej powinna funkcjonować odpowiednia struktura sieciowa sterowania rozwojem turystyki, posiadająca formalne uprawnienia i rzeczywiste możliwości do planowania i wdrażania strategii rozwoju turystyki dla tego obszaru. Dzięki temu obszar recepcji turystycznej można uznać za świadomie zarządzany podmiot strony podażowej rynku turystycznego, „...gdzie celem marketingowym tego zarządzania jest zdobycie mocnej pozycji w konkurencji rynkowej z innymi obszarami recepcji turystycznej, przy poszanowaniu zasad zrównoważonego rozwoju, a weryfikatorem tej pozycji jest klient (turysta) i dokonywane przez niego wybory" (Żemła, 2010: 29). Jednocześnie M. Żemła (2010) dodaje, że określenie obszaru recepcji turystycznej jako podmiotu rynkowego pozostaje w sprzeczności z klasycznymi i neoklasycznymi zasadami ekonomii i możliwe jest przede wszystkim na gruncie nowej ekonomii instytucjonalnej. Powodem takiego stanu jest fakt, że obszar recepcji turystycznej trudno uznać za organizację formalną, w której wyraźnie można wyodrębnić strukturę i granicę. Ponadto zarządzanie obszarem recepcji turystycznej, czy raczej regulacja tego obszaru, odbywa się na fundamencie nieformalnych powiązań niezależnych podmiotów, które łączy oferowanie wspólnego i zintegrowanego produktu na rynku turystycznym w percepcji turystów.

Obszar recepcji turystycznej jest niezwykle złożony w kontekście zaspokajania potrzeb turystów. Ten sam obszar może bowiem oferować kilka produktów skierowanych do różnych grup odbiorców, co powoduje, że system zarządzania obszarem jest bardzo rozbudowany (Middleton, Hawkins, 1998). Dodatkowo za kryterium weryfikujące obszar recepcji turystycznej uznaje się takie składniki konsumpcji turystycznej, jak (Dziedzic, 1998): walory turystyczne, które po przystosowaniu do potrzeb ruchu turystycznego stanowią atrakcje turystyczne; usługi świadczone przez urządzenia obsługowe; usługi infrastruktury ogólnej; dostępność komunikacyjną. Konsumpcja turystyczna składa się jednak z wielu pozornie niezależnych elementów, które muszą być dostarczone w odpowiednim miejscu i czasie, aby podróż turystyczna mogła się odbyć. Ponadto na podróż turystyczną składa się ciąg decyzji i działań konsumentów podejmowanych w różnych miejscach i w ciągu pewnego czasu. To wszystko daje pewien obraz, że wszystkie składniki konsumpcji turystycznej podporządkowane są oczekiwaniom, które powstały w umyśle turysty w czasie planowania podróży, a wymienione wcześniej dobra i usługi nie są produktem z punktu widzenia turysty, tylko bazą do wykreowania produktu będącego całością przeżyć turysty (Marczak, Borzyszkowski 2009).

$\mathrm{Na}$ fundamencie rozważań o konsumpcji w turystyce obszar recepcji turystycznej można przedstawić jako produkt będący pewną całością „...elementów materialnych i niematerialnych, stanowiących podstawę istniejącego w umyśle turysty wyobrażenia i oczekiwań związanych z pobytem w danym miejscu" (Dziedzic, 1998: 23). Pojawienie się produktu obszaru recepcji turystycznej związane jest z wykorzystaniem przez obszary dorobku teorii i pragmatyki marketingu i przyjęcia orientacji marketingowej, co zdaniem T. Żabińskiej (2000) może się przyczynić do skutecznego zarządzania rozwojem turystyki z uwzględnieniem lokalnych warunków, właściwie pojętych interesów społeczności lokalnej oraz turystów. Jak uważa M. Żemła (2011: 1073), produkt obszaru recepcji turystycznej „....stanowi konglomerat znacznej liczby produktów o wieloaspektowych powiązaniach i relacjach, a przede wszystkim wytwarzanych przez różne podmioty, które dążą do realizacji różnych, niekiedy sprzecznych ze sobą celów”. Dobitnie zagadnienie to przedstawia macierz zgodności i sprzeczności celów społeczności lokalnych, podmiotów gospodarczych oraz środowisk ochrony przyrody i kultury zaangażowanych w rozwój turystyki na szczeblu lokalnym (Szczechowicz, 2010). 


\section{PRODUKT OBSZARU RECEPCJI TURYSTYCZNEJ A KONSUMPCJA ZRÓWNOWAŻONA W TURYSTYCE}

Coraz częściej obszary recepcji turystycznej zaczynają przyjmować strategie i plany zarządzania oparte na turystyce zrównoważonej, jednak nadal skala tego zjawiska ogranicza się do nielicznych przykładów dobrych praktyk i indywidualnych projektów. Zmianą w tym przypadku może być określenie współczesnego priorytetu i kierunku dotyczącego zrównoważonego rozwoju turystyki europejskiej, który odwołuje się wprost do konieczności rozwoju obszarów recepcji turystycznej w zgodzie z założeniami zrównoważonego rozwoju oraz dążeniem do zrównoważonych wzorców konsumpcji turystycznej (Podstawowe wytyczne dla zrównoważonej turystyki europejskiej, 2003). Kształt ustalonych priorytetów związany jest ze specyfiką struktury przestrzennej turystyki, która sprawia, że problemy rozwoju turystyki powinny być rozpatrywane głównie na szczeblu lokalnym i regionalnym, bowiem to właśnie na konkretnych obszarach dochodzi do największej części konsumpcji turystycznej, z wszelkimi pozytywnymi i negatywnymi tego konsekwencjami (Goranczewski, Puciato, 2010).

Zagadnieniem wymagającym szczególnego odniesienia do konsumpcji zrównoważonej w turystyce jest produkt obszaru recepcji turystycznej, który ze względu na swą ogólną specyfikę, różnorodność potrzeb zgłaszanych przez turystów oraz zróżnicowany stopień zaangażowania w proces zaspokajania własnych potrzeb, nie jest tak jednoznaczny w ogólnej interpretacji. Odniesienie produktu obszaru recepcji turystycznej do konsumpcji zrównoważonej w turystyce przedstawia tabela 1 . Wyodrębniono w tym celu cechy produktu turystycznego oddające szczegółowo istotę opisywanego produktu.

Tab. 1. Produkt obszaru recepcji turystycznej w odniesieniu do konsumpcji zrównoważonej w turystyce

\begin{tabular}{|c|c|c|}
\hline $\begin{array}{l}\text { Cechy produktu obszaru } \\
\text { recepcji turystycznej }\end{array}$ & Opis cechy & $\begin{array}{l}\text { Odniesienie do konsumpcji } \\
\text { zrównoważonej w turystyce }\end{array}$ \\
\hline $\begin{array}{l}\text { Charakter usługowy } \\
\text { i cechy typowe } \\
\text { dla produktów } \\
\text { niematerialnych }\end{array}$ & $\begin{array}{l}\text { Produkt obszaru recepcji turystycznej } \\
\text { jest w przeważającej części produktem } \\
\text { o charakterze niematerialnym, } \\
\text { usługowym, posiadając jednocześnie } \\
\text { wszystkie cechy typowe przypisywane } \\
\text { produktom usługowym. }\end{array}$ & $\begin{array}{l}\text { Produkt obszaru recepcji turystycznej } \\
\text { wpisuje się w zjawisko serwicyzacji. } \\
\text { Zastąpienie dóbr i usług materialnych } \\
\text { niematerialnymi traktowane jest } \\
\text { wprost jako element istoty konsumpcji } \\
\text { zrównoważonej w turystyce. } \\
\end{array}$ \\
\hline & \multirow{2}{*}{$\begin{array}{l}\text { Odczuwane przeżycia turysty } \\
\text { dotyczą nie tyle samych materialnych } \\
\text { i niematerialnych elementów produktu } \\
\text { obszaru recepcji turystycznej, co } \\
\text { sposobu ich wykorzystania przez } \\
\text { poszczególnych odwiedzających. } \\
\text { Decyzje odwiedzającego dotyczące } \\
\text { tego, z których usług i walorów } \\
\text { skorzystać podczas pobytu w obszarze } \\
\text { recepcji turystycznej, i w jaki } \\
\text { sposób, a nawet jego zaangażowanie } \\
\text { emocjonalne, stan psychiki, } \\
\text { wynikający niekoniecznie z przyczyn } \\
\text { związanych z jego pobytem w danym } \\
\text { obszarze recepcji turystycznej, } \\
\text { w istotny sposób kształtują produkt } \\
\text { konsumowany przez odwiedzającego } \\
\text { i wpływają istotnie na jego } \\
\text { postrzeganą jakość. }\end{array}$} & \multirow{2}{*}{$\begin{array}{l}\text { Zrównoważony charakter konsumpcji } \\
\text { zależy w głównej mierze od } \\
\text { indywidualnego podejścia konsumenta } \\
\text { do produktu. Odnosi się to zarówno } \\
\text { do produktów zgodnych z ideą } \\
\text { zrównoważonego rozwoju, jak i do } \\
\text { produktów zupełnie odmiennych. } \\
\text { Zauważalny wzrost zachowań } \\
\text { konsumentów na rynku } \\
\text { turystycznym w kierunku konsumpcji } \\
\text { zrównoważonej będzie prowadził } \\
\text { do większego zaangażowania } \\
\text { podmiotów zarządzających turystyką } \\
\text { na danym obszarze oraz podmiotów } \\
\text { strony podaży do kreowania } \\
\text { produktów spełniających oczekiwania } \\
\text { konsumentów zrównoważonych oraz } \\
\text { zaspokajających ich potrzeby. }\end{array}$} \\
\hline $\begin{array}{l}\text { W pr } \\
\text { prod } \\
\text { rolę c } \\
\text { decyz } \\
\text { kons }\end{array}$ & & \\
\hline
\end{tabular}




\begin{tabular}{|c|c|c|}
\hline $\begin{array}{l}\text { Cechy produktu obszaru } \\
\text { recepcji turystycznej }\end{array}$ & Opis cechy & \\
\hline $\begin{array}{l}\text { Produkt obszaru recepcji } \\
\text { turystycznej ma charakter } \\
\text { złożony, a całościowe } \\
\text { doświadczenie konsumenta } \\
\text { jest sumą przeżyć } \\
\text { związanych z korzystaniem } \\
\text { z poszczególnych usług } \\
\text { i walorów oraz ogólnego } \\
\text { doświadczenia związanego } \\
\text { z przebywaniem w określonym } \\
\text { miejscu. }\end{array}$ & $\begin{array}{l}\text { Przeżycie związane z pobytem } \\
\text { w danym miejscu jest przeżyciem } \\
\text { całościowym i obejmuje } \\
\text { doświadczenia związane ze } \\
\text { wszystkim, co dany odwiedzający } \\
\text { robił w danym miejscu, ale także } \\
\text { swego rodzaju doświadczenie } \\
\text { przebywania w nim. }\end{array}$ & \multirow{2}{*}{$\begin{array}{l}\text { Realizacja konsumpcji } \\
\text { zrównoważonej na obszarze } \\
\text { recepcji turystycznej wymaga } \\
\text { podejścia holistycznego, } \\
\text { uwzględniającego szereg } \\
\text { elementów składających się na } \\
\text { produkt obszaru. } \\
\text { Realizacja konsumpcji } \\
\text { zrównoważonej dotyczy } \\
\text { wszystkich elementów produktu } \\
\text { obszaru i odbywa się na każdym } \\
\text { etapie podróży. Niedopuszczalne } \\
\text { jest traktowanie przez konsumenta } \\
\text { charakteru zrównoważonej } \\
\text { konsumpcji fragmentarycznie, } \\
\text { a więc na zasadzie realizacji tylko } \\
\text { wybranych elementów produktu. }\end{array}$} \\
\hline $\begin{array}{l}\text { Produkt nie jest prostą sumą } \\
\text { poszczególnych elementów, } \\
\text { gdyż wartość dla klienta } \\
\text { powstaje często nie podczas } \\
\text { konsumpcji poszczególnych } \\
\text { produktów prostych } \\
\text { oferowanych w obszarze } \\
\text { recepcji turystycznej, ale } \\
\text { niejako pomiędzy nimi. }\end{array}$ & \multirow{3}{*}{ 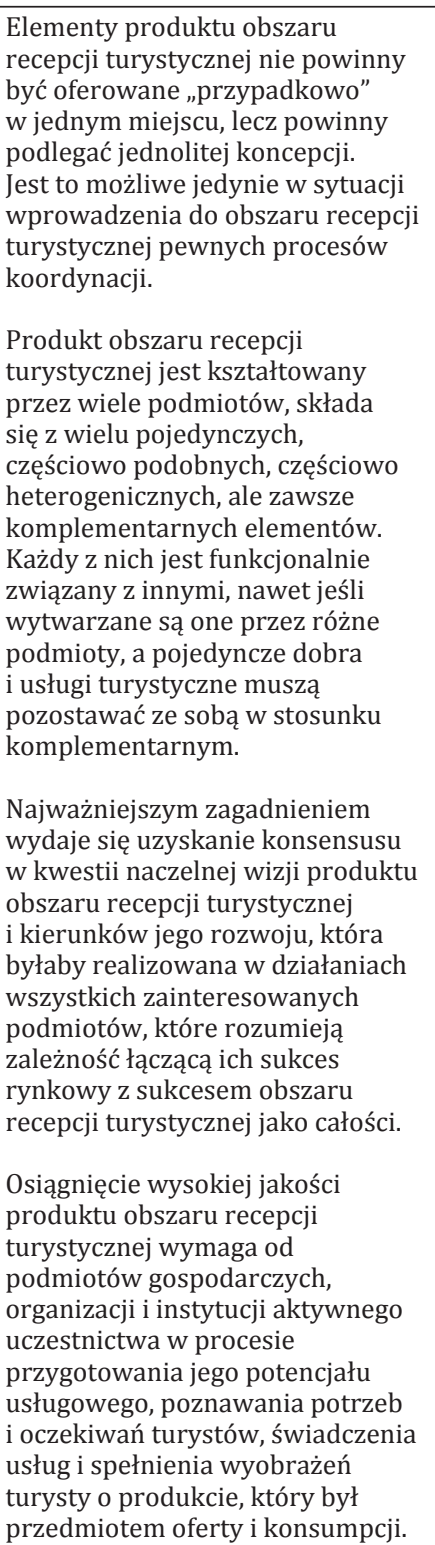 } & \\
\hline $\begin{array}{l}\text { Jakość produktu zależy } \\
\text { od dopasowania do siebie } \\
\text { poszczególnych elementów, } \\
\text { które powinny tworzyć } \\
\text { jednorodną koncepcyjnie } \\
\text { całość. }\end{array}$ & & \multirow{2}{*}{$\begin{array}{l}\text { Kształtowanie produktu } \\
\text { obszaru recepcji turystycznej } \\
\text { zgodnie z koncepcją turystyki } \\
\text { zrównoważonej jest przykładem } \\
\text { niezwykle trudnej w realizacji } \\
\text { idei opartej na jednym ogólnym } \\
\text { celu. W tym przypadku charakter } \\
\text { działań jest w większości sprzeczny } \\
\text { z ekonomicznymi przesłankami } \\
\text { podmiotów współuczestniczących } \\
\text { w kształtowaniu produktu, dlatego } \\
\text { fundamentalnym zadaniem jest } \\
\text { wspólne wypracowanie zgody co } \\
\text { do realizacji takiego produktu. } \\
\text { Wzrost zainteresowania wśród } \\
\text { konsumentów turystycznych } \\
\text { zrównoważonym charakterem } \\
\text { konsumpcji wymusza na } \\
\text { podmiotach współtworzących } \\
\text { produkt obszaru recepcji } \\
\text { turystycznej skoordynowanych } \\
\text { działań na rzecz jego dostosowania } \\
\text { do oczekiwań i potrzeb } \\
\text { konsumentów. Identyfikacja } \\
\text { zachodzących zmian rynkowych, } \\
\text { w tym przypadku opartych na } \\
\text { konsumpcji zrównoważonej, i ich } \\
\text { właściwa interpretacja może } \\
\text { prowadzić do osiągnięcia przewagi } \\
\text { konkurencyjnej produktu. }\end{array}$} \\
\hline $\begin{array}{l}\text { Wykreowanie jednorodnego } \\
\text { koncepcyjnie produktu } \\
\text { możliwe jest jedynie na drodze } \\
\text { długofalowej, uświadomionej } \\
\text { lub nieuświadomionej } \\
\text { współpracy wielu } \\
\text { różnorodnych podmiotów } \\
\text { realizujących wspólną wizję, } \\
\text { pozwalającą na osiąganie } \\
\text { indywidualnych sukcesów } \\
\text { poszczególnych podmiotów } \\
\text { tworzących składowe } \\
\text { złożonego produktu. }\end{array}$ & & \\
\hline
\end{tabular}




\begin{tabular}{|c|c|c|}
\hline $\begin{array}{l}\text { Cechy produktu obszaru } \\
\text { recepcji turystycznej }\end{array}$ & Opis cechy & $\begin{array}{c}\text { Odniesienie do konsumpcji } \\
\text { zrównoważonej w turystyce }\end{array}$ \\
\hline $\begin{array}{l}\text { Wypracowanie wspólnej } \\
\text { wizji rozwoju produktu } \\
\text { akceptowanej przez absolutnie } \\
\text { wszystkie podmioty } \\
\text { współtworzące produkt } \\
\text { jest trudne, a w niektórych } \\
\text { przypadkach wręcz } \\
\text { niemożliwe, ze względu na } \\
\text { przeciwstawny charakter } \\
\text { celów poszczególnych } \\
\text { podmiotów. }\end{array}$ & $\begin{array}{l}\text { Produkt obszaru recepcji } \\
\text { turystycznej stanowi konglomerat } \\
\text { znacznej liczby produktów } \\
\text { o wieloaspektowych powiązaniach } \\
\text { i relacjach, a przede wszystkim } \\
\text { wytwarzanych przez różne } \\
\text { podmioty, które dążą do } \\
\text { realizacji różnych, niekiedy } \\
\text { sprzecznych ze sobą, celów. Ta } \\
\text { sprzeczność interesów pomiędzy } \\
\text { poszczególnymi podmiotami } \\
\text { współtworzącymi produkt } \\
\text { obszaru recepcji turystycznej jest } \\
\text { zrozumiała, biorąc pod uwagę, że, } \\
\text { z jednej strony, produkt ten jest } \\
\text { współtworzony przez podmioty } \\
\text { pozostające ze sobą niekiedy } \\
\text { w bezpośrednim stosunku } \\
\text { konkurencyjnym, z drugiej } \\
\text { strony, przez podmioty bardzo } \\
\text { zróżnicowane, począwszy od } \\
\text { przedsiębiorstw komercyjnych, } \\
\text { poprzez władze samorządowe i ich } \\
\text { agendy, inne podmioty sektora } \\
\text { publicznego, stowarzyszenia } \\
\text { i podmioty sektora non-profit, } \\
\text { podmioty publiczno-prywatne, aż } \\
\text { na mieszkańcach kończąc. }\end{array}$ & $\begin{array}{l}\text { Wielowymiarowy charakter ról } \\
\text { przypisanych konsumentom } \\
\text { zrównoważonym odnosi się } \\
\text { do czynnego uczestnictwa we } \\
\text { wspieraniu i współtworzeniu } \\
\text { inicjatyw na rzecz turystyki } \\
\text { zrównoważonej. }\end{array}$ \\
\hline $\begin{array}{l}\text { W ramach jednego obszaru } \\
\text { recepcji turystycznej możliwe } \\
\text { jest oferowanie kilku } \\
\text { produktów nakierowanych } \\
\text { na zaspokajanie potrzeb } \\
\text { turystów należących } \\
\text { do innych segmentów } \\
\text { i oczekujących innych form } \\
\text { spędzania czasu w miejscu } \\
\text { docelowym. W większości } \\
\text { przypadków niemożliwe jest } \\
\text { jednak całkowite oddzielenie } \\
\text { od siebie poszczególnych } \\
\text { produktów, ponieważ wiele } \\
\text { elementów produktów } \\
\text { stanowi ich część wspólną } \\
\text { - z reguły jest to przede } \\
\text { wszystkim infrastruktura } \\
\text { ogólna i niektóre podstawowe } \\
\text { usługi turystyczne. Ponadto, } \\
\text { złożony i komplementarny } \\
\text { charakter wiązki motywów, } \\
\text { którymi kierują się turyści, } \\
\text { sprawia, że często podstawowe } \\
\text { atrakcje przyciągające jeden } \\
\text { segment turystów będą także } \\
\text { wykorzystywane jako atrakcje } \\
\text { dodatkowe dla osób o innym } \\
\text { preferowanym sposobie } \\
\text { spędzania czasu. }\end{array}$ & $\begin{array}{l}\text { Wiązka potrzeb, którą turyści } \\
\text { zaspokajają podczas pobytu } \\
\text { w danej miejscowości, jest złożona. } \\
\text { Składa się na nią wiele rozmaitych } \\
\text { potrzeb, wśród których jedynie } \\
\text { w niektórych przypadkach } \\
\text { można wyodrębnić główny cel } \\
\text { wyjazdu i cele uzupełniające, } \\
\text { a i tak ta hierarchia może ulec } \\
\text { zmianie podczas konsumpcji } \\
\text { produktu turystycznego. Osoby } \\
\text { należące do jednego segmentu } \\
\text { często korzystają także z atrakcji } \\
\text { przygotowanych z myślą o innym } \\
\text { segmencie. }\end{array}$ & $\begin{array}{l}\text { Niedobór zrównoważonej } \\
\text { oferty turystycznej wymaga od } \\
\text { konsumentów zrównoważonych } \\
\text { korzystania w możliwie } \\
\text { zrównoważony sposób } \\
\text { z produktów turystycznych } \\
\text { skierowanych do różnych } \\
\text { segmentów. } \\
\text { Różnorodność produktów } \\
\text { turystycznych i ich jakość } \\
\text { wpływa na konsumentów } \\
\text { w wieloraki sposób. W przypadku } \\
\text { indywidualnych działań } \\
\text { podmiotów kształtujących } \\
\text { produkt obszaru recepcji } \\
\text { turystycznej, skierowanych } \\
\text { w stronę konsumentów, zachodzi } \\
\text { ryzyko wydania jednoznacznej } \\
\text { opinii przez konsumenta } \\
\text { w stosunku do całego obszaru, } \\
\text { pomimo jego oceny dotyczącej } \\
\text { tylko jednego podmiotu lub } \\
\text { jednego produktu występującego } \\
\text { na obszarze. Istnieje przez to } \\
\text { potrzeba skoordynowanych } \\
\text { i wspólnych działań podmiotów, } \\
\text { ograniczających szereg } \\
\text { konsekwencji. }\end{array}$ \\
\hline
\end{tabular}

Źródło: odniesienie do konsumpcji zrównoważonej w turystyce stanowi autorskie opracowanie; pozostałą część zaczerpnięto z: Żemła (2010: 30-46). 


\section{ZAKOŃCZENIE}

Pojęcie produktu turystycznego jest niezwykle trudne do zdefiniowania. W orientacji marketingowej za produkt uważa się „...wszystko, co jest oferowane na rynku, aby zaspokoić pragnienia i potrzeby konsumentów" (Holloway, Robinson, 1997: 114). Bezpośrednie odniesienie produktu do turystyki rodzi pewne komplikacje ze względu na złożoność produktu turystycznego, który może obejmować miejsce, usługę, pakiety usług oraz produkty materialne (Holloway, Robinson, 1997). Wprawdzie większość produktów turystycznych składa się w całości lub w większości z usług to ich złożoność i wielowymiarowy charakter wymaga uwzględniania różnych ujęć, również w odniesieniu do jego poszczególnych składników spełniających odmienne role (Kruczek, Walas, 2009).

Jak zauważa A. Niezgoda (2011), pojawiające się trendy związane z realizacją zasad zrównoważonego rozwoju oraz zmiany w stylu życia mogą wpływać na zmianę postaw wśród podmiotów odpowiedzialnych za kreowanie produktów turystycznych i ich konsumentów. Takich wniosków dostarcza analiza wielowymiarowości zjawisk zachodzących na współczesnym rynku turystycznym, której przykładem jest analiza zmian zachowań konsumentów, wymuszająca reakcję podaży rynku turystycznego, i zmian składowych produktu turystycznego (Niezgoda, 2013). Coraz częściej pojawiają się również sygnały rynkowe, że realizacja zasad zrównoważonego rozwoju w turystyce poprzez konsumpcję zaczyna być elementem warunkującym jej rozwój, co może stanowić w dłuższej perspektywie istotną cechę wyróżniającą sektor turystyki na tle innych sektorów usług (Hendel, Żemła, 2016).

Produkt obszaru recepcji turystycznej jest przykładem na to, że brak uwzględnienia specyfiki rynku turystycznego w rozważaniach nad turystyką powoduje, że zagadnienie może nie zostać $\mathrm{w}$ pełni wyjaśnione lub nawet jego poznanie może zostać całkowicie zaburzone. Postulat o zachowaniu bezpośredniego odniesienia pojęć funkcjonujących w wielu dyscyplinach naukowych do turystyki nie pojawia się bez przyczyny. Rozważania nad produktem obszaru recepcji turystycznej i konsumpcją pokazały, że już na etapie dość ogólnych wniosków pojawiają się wątpliwości i niejednoznaczność. Tym samym próba odniesienia pojęcia produktu obszaru recepcji do tak szczegółowego zagadnienia, jakim jest konsumpcja zrównoważona w turystyce, wydaje się wyzwaniem wymagającym dalszych badań. Jednym z nich może być badanie relacji między produktem obszaru recepcji turystycznej a konsumpcją zrównoważoną w turystyce w warunkach rzeczywistości funkcjonalnej. Przedstawione w artykule rozważania mogą stać się zatem przyczynkiem do dyskusji.

\section{Literatura \\ References}

Borys, T. (2011). Zrównoważony rozwój - jak rozpoznać ład zintegrowany. Problemy Ekorozwoju, $6(2), 75-81$.

Borys, T. (2016). 0 dwóch komplementarnych ujęciach nowego paradygmatu konsumpcji. Prace Naukowe Uniwersytetu Ekonomicznego we Wrocławiu, 452, 22-31.

Cieślikowski, K., Żemła, M. (2002). Pozycjonowanie obszaru recepcji turystycznej z wykorzystaniem map percepcji. Marketing i Rynek, 2, 20-26. 
Durydiwka, M., Kowalczyk, A., Kulczyk, S. (2010). Definicja i zakres pojęcia „turystyka zrównoważona". W: A. Kowalczyk (red.). Turystyka zrównoważona. Warszawa: Wydawnictwo Naukowe PWN, 21-43.

Dziedzic, E. (1998). Obszar recepcji turystycznej jako przedmiot zarządzania strategicznego. Warszawa: Szkoła Główna Handlowa.

Goranczewski, B., Puciato, D. (2010). Zastosowanie analizy SWOT w formułowaniu strategii rozwoju turystyki na obszarach recepcyjnych. Turyzm, 20(2), 47-55.

Hendel, M. (2016). Koncepcja konsumpcji zrównoważonej w turystyce jako możliwość realizacji założeń turystyki zrównoważonej. Marketing i Rynek, 2, 13-19.

Hendel, M., Żemła, M. (2016). Zrównoważona konsumpcja jako atrybut i uwarunkowanie rozwoju branży turystycznej w XXI wieku. Prace Komisji Geografii Przemysłu Polskiego Towarzystwa Geograficznego, 30(4), 187-197.

Holloway, J.C, Robinson, C. (1997). Marketing w turystyce. Warszawa: Polskie Wydawnictwo Ekonomiczne.

Huang, M.H., Rust, R.T. (2011). Sustainability and consumption. Journal of the Academy of Marketing Science, 39(1), 40-54.

Jaros, B. (2016). Bariery i pozytywne tendencje w rozwoju zrównoważonej konsumpcji w Polsce. Ekonomia i Środowisko, 57(2), 24-36.

Kiełczewski, D. (2004). Konsumpcja a perspektywy trwałego i zrównoważonego rozwoju. Białystok: Wydawnictwo Uniwersytetu w Białymstoku.

Kiełczewski, D. (2008). Sektor publiczny a kształtowanie wzorców trwałej konsumpcji. Optimum. Studia Ekonomiczne, 40(4), 75-92.

Kiełczewski, D. (2012). Różnorodność stylów życia jako czynnik rozwoju zrównoważonego. Ekonomia i Środowisko, 43(3), 73-84.

Kruczek, Z., Walas, B. (2009). Nowoczesne postrzeganie promocji kulturowych produktów turystycznych. W: A. Stasiak (red.). Kultura i turystyka - wspólnie zyskać. Łódź: Wydawnictwo Wyższej Szkoły Turystyki i Hotelarstwa, 335-360.

Lorek, E. (2011). Ekonomia zrównoważonego rozwoju w badaniach polskich i niemieckich. Studia Ekonomiczne. Zeszyty Naukowe Uniwersytetu Ekonomicznego w Katowicach, 90, 103-112.

Marczak, M., Borzyszkowski, J. (2009). Region (obszar) jako produkt turystyczny. Zeszyty Naukowe Wydziału Nauk Ekonomicznych Politechniki Koszalińskiej, 13, 117-126.

Meyer, B. (2011). Turystyka a ład przestrzenny. Wzajemne relacje. Turyzm, 21(1-2), 25-32.

Middleton, V.T.C., Hawkins, R. (1998). Sustainable tourism: A marketing perspective. Londyn: Routledge.

Nawrot, Ł., Zmyślony, P. (2009). Międzynarodowa konkurencyjność regionu turystycznego. Od programowania rozwoju do zarządzania strategicznego. Kraków: Wydawnictwo PROKSENIA.

Niezgoda, A. (2006). Obszar recepcji turystycznej w warunkach rozwoju zrównoważonego. Poznań: Wydawnictwo Akademii Ekonomicznej w Poznaniu.

Niezgoda, A. (2011). Rola działań proekologicznych w kształtowaniu produktu turystycznego. Turyzm, 21(1-2), 33-40.

Niezgoda, A. (2013). Prosumers in The Tourism Market: The Characteristic and Determinants of Their Behaviour. Poznan University of Economics Review, 13(4), 130-141.

Podstawowe wytyczne dla zrównoważonej turystyki europejskiej (2003). Komunikat Komisji Wspólnot Europejskich do Rady, Parlamentu Europejskiego, Europejskiego Komitetu Ekonomiczno-Społecznego oraz Komitetu Regionów COM(2003)516.

Przecławski, K. (1973). Turystyka a wychowanie. Warszawa: Nasza Księgarnia.

Sharpley, R. (2015). Sustainability: A Barrier to Tourism Development. W: R. Sharpley, D.J. Telfer (red.). Tourism and Development. Concept and Issues, Second Edition. Bristol, Buffalo and Toronto: Channel View Publications, 428-452.

Smoleński, M. (2012). Modelowanie przestrzeni turystycznej peryferyjnych regionów turystycznych. Ekonomia i Zarządzanie, 4(1), 64-91.

Szczechowicz, B. (2010). Zrównoważony rozwój obszarów recepcji turystycznej - grupy interesów i źródła konfliktów. Folia Turistica, 22, 167-184.

UNWTO (2013). UNWTO World Tourism Barometer, 11.

Zaręba, D. (2010). Ekoturystyka. Warszawa: Wydawnictwo Naukowe PWN. 
Żabińska, T. (2000). Wybrane modele strategii marketingowych w usługach i turystyce na tle ich paradygmatów. W: L. Żabiński (red.). Modele strategii marketingowych. Wybrane ujęcia paradygmatyczne i sektorowe. Katowice: Wydawnictwo Akademii Ekonomicznej w Katowicach, 53-82.

Żemła, M. (2010). Wartość dla klienta w procesie kształtowania konkurencyjności obszaru recepcji turystycznej. Katowice: Górnośląska Wyższa Szkoła Handlowa im W. Korfantego w Katowicach.

Żemła, M. (2011). Rola mieszkańców w budowie produktu obszaru recepcji turystycznej - przyczynek do dyskusji. Prace Naukowe Uniwersytetu Ekonomicznego we Wrocławiu, 157, 10721081.

Marek Hendel, mgr, były doktorant kierunku ekonomia na Wydziale Ekonomii, Zarządzania i Turystyki Uniwersytetu Ekonomicznego we Wrocławiu. Obecnie doktorant kierunku zarządzanie na Wydziale Zarządzania Uniwersytetu Ekonomicznego w Katowicach. Pracownik dydaktyczny Górnośląskiej Wyższej Szkoły Handlowej w Katowicach. Zainteresowania badawcze związane są ze zrównoważonym rozwojem turystyki, zachowaniami konsumentów na rynku turystycznym oraz rolą samorządu terytorialnego w rozwoju turystyki.

Marek Hendel, M.Sc., former Ph.D. student of Economics at the Wroclaw University of Economics, Faculty of Economics, Management and Tourism. Currently a Ph.D. student of Management at University of Economics in Katowice, Faculty of Management. Member of the teaching staff in Katowice School of Economics. His research interests are related to sustainable tourism development, consumers' behaviour on the tourist market and the role of local government in tourism development.

\section{Adres/address:}

Uniwersytet Ekonomiczny w Katowicach

Wydział Zarządzania

ul. 1 maja 50, 40-287 Katowice, Polska

e-mail: hendel.marek@gmail.com 